\title{
Zinc Finger Protein 42 Homolog
}

National Cancer Institute

\section{Source}

National Cancer Institute. Zinc Finger Protein 42 Homolog. NCI Thesaurus. Code C94684.

Zinc finger protein 42 homolog ( $310 \mathrm{aa}, \sim 35 \mathrm{kDa}$ ) is encoded by the human ZFP42 gene.

This protein may be involved in the modulation of both stem cell proliferation and transcription. 